\title{
A Semantical Analysis on Slogan
}

\author{
Randiyanto Pobela ${ }^{1}$, Meity Muntuuntu ${ }^{2}$,Jenie Posumah ${ }^{3}$ \\ Manado State University, Kampus Unima Street, Tondano, Indonesia \\ English Education Department, Manado State University, Kotamobagu, Indonesia \\ Email: randiypt@gmail.com, Meitymuntuuntu@unima.ac.id, Jenieposumah67@gmail.com
}

\begin{abstract}
:
This study uses a qualitative descriptive method to obtain data through direct observation. There are three elements of semantic meaning, namely lexical, grammatical, and contextual. However, this study only analyses the lexical meaning. This study aims to determine the types and meanings of the slogans in Tondano, especially those taken in several streets and offices. The data is obtained as a result of this study through documentation, namely; (1) Slogans on the streets and offices in Tondano city consist of 2 types, namely Educational slogans around 15 slogans and Product slogans around 7 slogans. Educational slogans are sentences that contain meanings related to learning. Product slogans are a form of sentence that contains the meaning of promotions, tips, and notifications about goods. Slogans have lexical meanings to motivate every reader. Each slogan has its own meaning, depending on the type. Educational slogans influence the learning motivation of students, teachers, and all readers. Product slogans provide additional information about the product being promoted. Therefore, it is advisable to read the message on the slogan and apply it in everyday life. If so, then the messages contained in the slogans were successfully conveyed.
\end{abstract}

\section{Keywords : Semantical, Lexical meaning, Slogan, Educational slogan, Product slogan}

\section{INTRODUCTION}

Language has an important role in life, "Through language, humans can think and develop their knowledge" (Hampp, 2019: 15). It also unites us all, for example; chatting, joking and much more. As a communication tool, language also has a role to be conveyed to others. "Language is fundamental to all social processes, and humans do need language to communicate with each other" (Maru, Sudarsono, Samola. 2018: 7). However, in using language in communication, there are many misunderstandings. For example, in conveying information to others, how can we understand the language we use so that they can reply to it. When we are involved in the discussion forum and we want to happiness in communicating, but express it in a language that doesn't seem to refer to that happiness, such as "you're so great", that's a line of praise, which has a happy impact on others. "People use language to express inner thoughts and emotions, to understand complex and abstract thoughts, to learn to communicate with others to meet our wants or needs, and to set rules and maintain our culture" (Panambunan, Golda, Tulung, Maru, 2016 : 58). If language is a human medium for sharing information, then by using language we can express whatever is on our thoughts and feelings. If so, we can find out any information about our lives. So, based on this statement, it can be imagined that language has a strategic position between humans and life. This statement has the same meaning as what Panambunan said above. As a society, we need information about life in order to live in harmony. "Communication is always important in everyday life, people need to communicate to interact with others and to express feelings or share ideas and thoughts" (Liando, Sahetapy, \& Maru, 2018: 1-16).

Language is a problem that causes people to misunderstand its meaning, due to several causes that are often overlooked. In this case, language does not only refer to what is expressed orally, but also includes 
non-spoken language which is called "written language". For example, understanding the slogan as "written language", as a form of providing information to anyone who reads it. The slogan "Learning makes us smart" at that time have a good meaning as motivation in life. At the same time it also has a bad meaning, because the meaning of the slogan is determined by the human reading it and the paradigm to understand the meaning of the slogan. Prihantini (2015: 182) states that "slogans are interesting and easy to remember short words or sentences to tell or convey something such as appeals, invitations, or prohibitions". Usually the slogan is found on posters, appeals, or advertisements (billboards). This is a form of semantic meaning in language which looks for the meaning of language, especially in the meaning of the slogan as "written language". We are talking about the slogan as "written language", based on a statement that makes us understand what a slogan is? And to find out the answer, we need knowledge for it. In this case, because slogans are part of language, it is necessary to know about meaning. This is a science of linguistics that focuses on meaning or is called "Semantics". Palmer in Aminuddin (2001: 15) states that "Semantics which originally comes from Greek, has a meaning to signify". As a technical term, semantics means the study of meaning.

Assuming that meaning is part of language, semantics is part of linguistics like sound and grammar. The definition of components in this case occupies a certain level. If the sound component generally occupies the first level, grammar at the second level, then the meaning component occupies the final level. Such is the statement about the knowledge we need to understand this slogan. And then, in this case, English language slogans. That is, the slogan written in English. A slogan as a general meaning is a short sentence that has many meanings. So, in this study we are not only understand the meaning of the slogan as a local language but also the international language, namely English. In Indonesia, English as a foreign language is not easily understood by Indonesian students. But working hard to learn a language is the only way to understand the language. To learn a foreign language, we need time to memorize vocabulary so that later we can speak the foreign language. "If people want to have good communication, they should improve their language skills because language is the basis of communication" (Liando, Maniku, Maru. 2016: 18). However, there is also misunderstanding of the sentence, and it leads to something else that only benefits one-sidedly. Like textbook merchants, who create slogans that entice customers to buy their books under the pretext of "studying." This is not really wrong, because there are 2 things that are assessed, namely (1) the language (2) the action. The researchers try to analyze the meaning of these slogans to gain new knowledge about the slogan. It's also to find the purpose of the person who created it. Actually, what the meaning of the sentence is? so that we can walk in accordance with meanings such as "Do not be noisy", what is clear is an order not to be noisy because you are holding a seminar, so you need calm so as not to be noisy because that is can be interrupted the seminar. However, if you misunderstand the meaning, it turns out that you are ignorant in responding to these orders, so that calm is never achieved, even though it is necessary.

In using language, there are messages in that language. The words or sentences that we say to others or in symbol form must contain information messages in any case. "Knowledge of the relationship between symbols or language units and their meaning is needed in communicating" (Chaer, 1995: 12). Furthermore, the real meaning is the content contained in a form or symbol, namely the relationship between symbols or language units in the outside world that is mutually agreed upon by language speakers. So that, they can understand each other. The meaning in a 
certain language, the origin and development of the meaning of a word can be known through semantical analysis. Therefore, the researchers raise the title of this research "A Semantical Analysis on the Slogan."

\section{RESEARCH METHODOLOGY}

\section{Research Design}

According to Sumanto, (2014: 179) that "descriptive qualitative activities involved collected the data to test hypotheses related to the status or condition of the object under study at the time of the study". Descriptive research attempts to describe and interpret what is there. This study is categorized into descriptive qualitative method.

The data collect through slogans are put on the streets and offices in Tondano only focuses on Product and Educational slogans. There are three steps to collect the data, the steps are as follows; Study Literature, in this step, the researchers search in documents or journal and also in the books as a study literature while consider about slogan to understanding the slogans for more. And then, decide the location of the research. And the second stepsis Observation, in this step, the researchers visit the location of the research. In this case, the location of the research is in Tondano especially on the streets and offices. The third steps is Documentation, in this step, the researchers take the documentations of the slogans in the streets and offices in Tondano. Then, researchers write each slogans as note before the researcher analyze.

\section{Data Analysis}

The procedures of analyzing the data are based on Miles and Huberman ways of analyzing qualitative data (1994: 10). The procedures are as follows : Data reduction, it is refers the proceses of simplifying that transforming that appear in written-up field notes or transcription (Miles and Huberman, 1994: 10). In this step, the slogans are collected and reduced. Data Display, The second major flow of analysis activity is data display. Generally display is an organized, compressed assembly of information that permits conclusion drawing and action (Miles and Huberman, 1994: 11). In this step, the writers describe the types of slogans. Conclusion Drawing, this activity is the third elements of qualitative analysis. Conclusion drawing involves stepping back to consider what the analyze data mean and to assess their implications for the questions at hand. In this step, the data are concluded as the finding of the research.

\section{FINDINGS AND DISCUSSION}

\section{Data Reduction}

Table 1: Slogans

\begin{tabular}{|l|l|}
\hline $\begin{array}{l}\text { Never stop } \\
\text { learning }\end{array}$ & $\begin{array}{l}\text { Do not waste your } \\
\text { time }\end{array}$ \\
\hline Do what your love & Simple is good \\
\hline $\begin{array}{l}\text { Believe you can } \\
\text { do it }\end{array}$ & $\begin{array}{l}\text { Work hard stay } \\
\text { humble }\end{array}$ \\
\hline $\begin{array}{l}\text { Never lose hope } \\
\text { Talent and } \\
\text { creativity }\end{array}$ \\
\hline $\begin{array}{l}\text { The fear of lord is } \\
\text { the beginning of } \\
\text { science \& } \\
\text { technology }\end{array}$ & $\begin{array}{l}\text { An empty vessel } \\
\text { make the most } \\
\text { noise, and empty } \\
\text { head make the } \\
\text { most talk }\end{array}$ \\
\hline $\begin{array}{l}\text { Dicipline is the } \\
\text { key of success }\end{array}$ & $\begin{array}{l}\text { Honestly is the } \\
\text { fundamental for a } \\
\text { good character }\end{array}$ \\
\hline $\begin{array}{l}\text { I am not only } \\
\text { teaching, I am } \\
\text { building student } \\
\text { character }\end{array}$ & $\begin{array}{l}\text { Good books are } \\
\text { more valuable } \\
\text { than fine clothes }\end{array}$ \\
\hline $\begin{array}{l}\text { Student today, } \\
\text { leader tomorrow }\end{array}$ & $\begin{array}{l}\text { Life begins with } \\
\text { coffee }\end{array}$ \\
\hline Coffee inspires me & Enjoy tea \\
\hline $\begin{array}{l}\text { Coffee is always a } \\
\text { good idea }\end{array}$ & $\begin{array}{l}\text { Idea start with a } \\
\text { great coffee } \\
\text { The yll you need is } \\
\text { ingredient and more } \\
\text { always love } \\
\text { love and } \\
\text { coffee }\end{array}$ \\
\hline
\end{tabular}




\section{Data Display}

Based on the research findings, the slogans types are as follows:

Table 2: Educational Slogans

\begin{tabular}{|l|l|}
\hline $\begin{array}{l}\text { Never stop } \\
\text { learning }\end{array}$ & $\begin{array}{l}\text { Do not waste your } \\
\text { time }\end{array}$ \\
\hline Do what your love & Simple is good \\
\hline $\begin{array}{l}\text { Believe you can do } \\
\text { it }\end{array}$ & $\begin{array}{l}\text { Work hard stay } \\
\text { humble }\end{array}$ \\
\hline Never lose hope & $\begin{array}{l}\text { Talent and } \\
\text { creativity }\end{array}$ \\
\hline $\begin{array}{l}\text { The fear of lord is } \\
\text { the beginning of } \\
\text { science } \\
\text { technology \& }\end{array}$ & $\begin{array}{l}\text { An empty vessel } \\
\text { make the most } \\
\text { noise, and empty } \\
\text { head make the } \\
\text { most talk }\end{array}$ \\
\hline
\end{tabular}

\begin{tabular}{|l|l|}
\hline $\begin{array}{l}\text { Dicipline is the } \\
\text { key of success }\end{array}$ & $\begin{array}{l}\text { Honestly is the } \\
\text { fundamental for a } \\
\text { good character }\end{array}$ \\
\hline $\begin{array}{l}\text { I am not only } \\
\text { teaching, I am } \\
\text { building student } \\
\text { character }\end{array}$ & $\begin{array}{l}\text { Good books are } \\
\text { more valuable } \\
\text { than fine clothes }\end{array}$ \\
\hline $\begin{array}{l}\text { Student today, } \\
\text { leader tomorow }\end{array}$ &
\end{tabular}

Table 3: Product slogans

\begin{tabular}{|l|l|}
\hline $\begin{array}{l}\text { Life begins with } \\
\text { coffee }\end{array}$ & $\begin{array}{l}\text { All you need is } \\
\text { love and more } \\
\text { coffee }\end{array}$ \\
\hline Coffee inspires me & Enjoy tea \\
\hline $\begin{array}{l}\text { Coffee is always a } \\
\text { good idea }\end{array}$ & $\begin{array}{l}\text { Idea start with a } \\
\text { great coffee }\end{array}$ \\
\hline $\begin{array}{l}\text { The secret } \\
\text { ingredient is } \\
\text { always love }\end{array}$ & \\
\hline
\end{tabular}

\section{Conclusion Drawing}

The slogans analysing on lexical meaning. Lexical meaning is an adjective form derived from the noun lexicon. The both types of the slogans are as follows :

\section{Educational Slogan}

Educational slogan is form that concerns about Education which in each sentence ignores the process or the Education system. This slogan serves to induce educators or students to pay more attention to Education. The researchers have an examples of Educational slogans. The slogans are as follows :

\section{The fear of God is the beginning of science \& technology}

This sentence consists of several words namely, fear, lord, beginning, science, and technology.

The word of "fear", means :

a. Feelings that require submission.

b. Sense that makes yourself become more aware of a big thing so reject it.

The word of "lord", means :

a. A person who has power that stands above everything.

b. The term for a ruler that is unmatched.

The word of "beginning", means :

a. An action that has just begun.

b. The earliest step of an action.

The word of "science", means :

a. Something that is understood and taught.

b. The expertise of someone learned by learning.

The word of "technology", means : a. Alternative media which embodies all human work.

b. The science which uses the concept of systematic thinking forms an orderly arrangement.

The overall lexical meaning is, trust in the creator, is the beginning of science and technology. That is to say, each of the behaviors as learners is necessary to hold principles. 


\section{I am not only teaching, I am building student character}

This sentence consists of several words namely, I, am, not, only, teaching, I, am, building, student, character.

The word of " $\boldsymbol{I}$ ", means :

a. A self-expression as a subject when speaking.

b. Personal pronouns in certain situations in conversation.

The word of "am", means :

a. A complementary word for nouns, verbs, and natures.

b. Is to be to complete basic words.

The word of "not", means :

a. Reject the will of an invitation or offer ideas.

b. Something that refuses whatever is given.

The word of"only", means :

a. Exception form of certain choices.

b. The form used in expressions when there are still doubts about them.

The word of "teaching", means :

a. Giving all knowledge to others with directed milk.

b. The form of methods used to transfer knowledge to students.

The word of " $\boldsymbol{I}$ ", means :

a. A self-expression as a subject when speaking.

b. Personal pronouns in certain situations in conversation.

The word of " $a m$ ", means :

a. A complementary word for nouns, verbs, and natures.

b. Is to be to complete basic words.

The word of "building", means :

a. Activities undertaken to arrange something separate to be whole. b. Actions involving physical and psychological that create ideas to solve problems.

The word of "student", means :

a. Students who are bound in the bureaucratic system in learning.

b. The person in charge of completing learning from the teacher who teaches it.

The word of "character", means :

a. A behavior or habits of people that are unique to themselves.

b. Habits inherent in people living their lives.

The overall lexical meaning is, as a teacher, he is not only tasked with teaching students, but also shapes their characters.

\section{Product slogan}

Product slogan is a slogan that refers to the form of supply of goods to a wide audience. Like a sale that makes an add about it sale so that it can be seem by buyers. The researchers have an examples of Product slogans. The slogans are as follows :

\section{Coffee inspires me}

This sentence consists of several words namely, coffee, inspires, and me.

The word of "coffee", means:

a. A drink made according to certain conditions.

b. The drinks that use only the sugar and coffee itself.

The word of "inspires", means:

a. Something that makes us get solutions to problems.

b. A thought that arises in the midst of a problem as a middle ground.

The word of "me", means:

a. A pronoun used to express oneself. 
b. The pronouns are used in nouns to indicate the possession of nouns.

The overall lexical meaning is, by drinking coffee we get a solution to the problem.

\section{All you need is love and more coffee}

This sentence consists of several words namely, all, you, need, is, love, and, more, and coffee.

The word of "all", means :

a. Refers to the whole that is around.

b. The phrase that represents all the other expressions that are voiced.

The word of "you", means :

a. Form of statement to describe others.

b. A name commonly used to call people who are not recognized by name.

The word of "need", means :

a. A very useful and important thing for success.

b. Something that must exist so that it becomes a complement to something.

The word of "is", means :

a. The form to be that connects the first sentence to the next sentence.

b. Tense statement for something you want to notify.

The word of "love", means :

a. A form of high awareness from the human heart.

b. The feeling that brings eternal strength in yourself so that it stands.

The word of "and", means :

a. Form of disclosure that exceeds someone or indicates the existence of something that is friendly.

b. Other forms of depiction of objects that accompany.

The word of "more", means :

a. Forms of words that describe more circumstances. b. Picture of the advantages of an object so as to clarify the objects around it.

The word of "coffee", means :

a. Something liquid or powder that is usually taken when cold.

b. The liquid is mixed with a deep black color and has a bitter taste.

The overall lexical meanings are, whatever you need is love and drinking lots of coffee, that is, for coffee drinkers, who put forward their idealistic addicts, then love in a glass of coffee is everything.

\section{Discussion}

There are short sentences contained in the slogans are definite meanings, but in fact the meaning was completely uncertain. There are even people who fulfil short sentences (slogans) and understand them without further examining the meaning of the slogan itself, which turn out to be so a broad in its explanation but in packaging that it is only a sentence to store words. In Educational slogan which in the sentence refers to something that makes the students, the teacher are motivated in the learning process, in the form of motivation to them. But sometimes, there are also some oddities in some people who understand slogans and think of them as unimportant and just put them aside. Some even are misinterpreted the slogans. Learning is intended by the school community as a form of reading, so they can understand it from another perspective. Then referring to books as a form of reading, which in a broad sense is not only that, but understanding our environment, if read a book, then after that understand what is around it.

In essence, when studying the theory of learning material, it should be equipped with practice as a refinement of the theory itself to gain a deep understand. Likewise, with product slogans, which are easier to cause misunderstandings when read them. Like the previous educational slogans, they only interpreted with a view that did not cover the whole so that 
misunderstandings could easily occur. Language is often the root of misunderstand in social life. In this case, the researchers are also interested in studying the meaning contained in the slogans order to get a new meaning. So that, this research can provides a new perspective to see the meaning contained in the slogan.

\section{CONCLUSSION \& SUGGESTION}

The researchers finds about 22 slogans in several offices and streets in Tondano. From the number of slogans found, the researchers divide them into 2 types of slogans as the focus of the study, namely 15 Educational slogans and 7 product slogans. The researchers also get the interpretation of the both types of slogans. In every slogan, there are several words that have a broad meaning so that people easily misunderstand if they look from just one angle, it takes several points of view to be able to understand them. After being analyzed, the researchers make a conclusion. The slogans have lexical meaning that motivate every reader. Each slogan has its own meanings, depending on the types. Educational slogans are affected in the learning motivation for students and teachers. The product slogan provides additional information about the product it is promoting. And also, everyone, who sees it, can read the both of those slogans types. That makes them motivate to life as be improve their selves.

The researchers suggest, regarding the slogans listed that have several meaning that is needed to be considered by the coming researchers, especially where the slogan is installed are some slogans are not in their proper place. For example on the slogan at the BMKG (Badan Meteorologi Klimatologi dan Geofisika) office, there are two types of slogans there, which actually do not match the location of the slogan. To be more precise of the slogans are posted in the right places, such as in schools for educational slogans, and in coffee shops for product slogans. They will have a good effect on people who read the message contained in the slogan. Thus the message contained in the slogan is successfully conveyed. In addition, to the readers, it is also useful for them to apply.

\section{REFERENCES}

Aminuddin, 2001. Semantic (Pengantar Studi Tentang Makna). Malang: Sinar Baru.

Emelia Panambunan, Golda J. Tulung, Mister Gidion Maru.2016. Improving Student's Speaking Ability Through Communicative Language Teaching Of The Second Level Students At "MEC" Megalia English Course.Vol.1, No 1. Pg. 58.

Chaer, Abdul. 1995. Pengantar Semantik Bahasa Indonesia. Jakarta: Rineka Cipta.

Hampp, Paula L. 2019. Use of Songs in Teaching Simple To be and Past Tense Teaching.Journal of English Language and Literature Teaching.Vol.4, No 1.P.15.

Liando, N. V. F., Sahetapy, R. J. V., Maru, M. G. (2018). English Major Students' Perceptions Towards Watching English Movies In Listening And Speaking Skills Development. Advances In Social Sciences Research Journal, 5(6), 1-16.

Liando, Nihta., Maniku, J., Maru, M.G. 2018. Watching Movie Clips as AStrategy to Improve Students, Listening Skill. Journal of English Language and Literature. JELLT, Vol 1, No 1.P.18.

Longman, 2000. Dictionary of American English, new edition. Laurence.

Maru, M. G., Sudarsono, L., Samola, N. 2016. A Discourse Analysis Figurative Language in Barrack H. Obama's Speech. Vol.4, No 1. 7.

Miles, M. B and A. M. Huberman. 1994. Qualitative Data Analysis $2^{\text {nd }}$ Edition. California: Sage Publication. 
Pardjimin. 2005. Bahasa Indonesia untuk SMP Kelas XIII. Bogor: Yudhistira.

Prihantini, Ainia. 2015. Master Bahasa

Indonesia.Yogyakarta: Bentang Pustaka.

Sumanto, 2014. Teori dan Aplikasi Metode Penelitian. Yogyakarta: Caps (Center of Academic Publishing Service). 